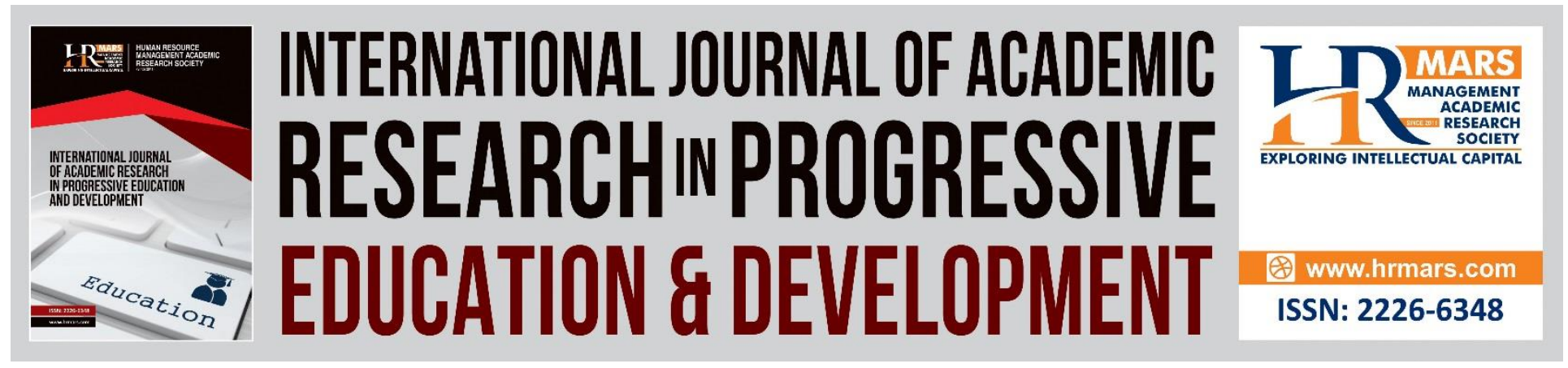

\title{
Metaphoric Drawing Narrative Career Counselling: Teaching Work Value and Career Identity Statuses via Experiential Learning Method
}

Sheau Tsuey Chong, Salina Nen, Thang Wei Xiong, Ong Gui Mei, Denise Koh, Nasrudin Subhi, Tan Joo Siang, Nicole Chen Lee Ping \& Shin Pui San

To Link this Article: http://dx.doi.org/10.6007/IJARPED/v10-i1/9623

DOI:10.6007/IJARPED/v10-i1/9623

Received: 04 January 2021, Revised: 30 January 2021, Accepted: 19 February 2021

Published Online: 26 March 2021

In-Text Citation: (Chong et al., 2021)

To Cite this Article: Chong, S. T., Nen, S., Xiong, T. W., Mei, O. G., Koh, D., Subhi, N., Siang, T. J., Ping, N. C. L., \& San, S. P. (2021). Metaphoric Drawing Narrative Career Counselling: Teaching Work Value and Career Identity Statuses via Experiential Learning Method. International Journal of Academic Research in Progressive Education and Development, 10(1), 671-685.

Copyright: (c) 2021 The Author(s)

Published by Human Resource Management Academic Research Society (www.hrmars.com)

This article is published under the Creative Commons Attribution (CC BY 4.0) license. Anyone may reproduce, distribute, translate and create derivative works of this article (for both commercial and non-commercial purposes), subject to full attribution to the original publication and authors. The full terms of this license may be seen at: $\underline{\text { http://creativecommons.org/licences/by/4.0/legalcode }}$

Vol. 10(1) 2021, Pg. 671 - 685

Full Terms \& Conditions of access and use can be found at http://hrmars.com/index.php/pages/detail/publication-ethics 


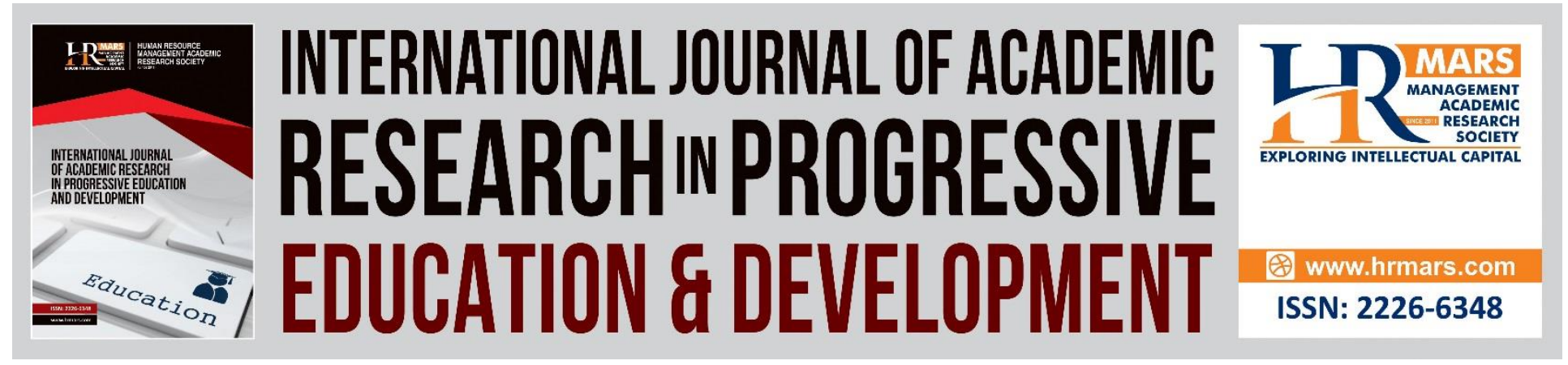

\title{
Metaphoric Drawing Narrative Career Counselling: Teaching Work Value and Career Identity Statuses via Experiential Learning Method
}

Sheau Tsuey Chong ${ }^{1}$, Salina Nen ${ }^{1}$, Thang Wei Xiong ${ }^{2}$, Ong Gui $\mathrm{Mei}^{1}$, Denise $\mathrm{Koh}^{3}$, Nasrudin Subhi ${ }^{1}$, Tan Joo Siang ${ }^{4}$, Nicole Chen Lee Ping ${ }^{5}$ \& Shin Pui San 6

${ }^{1}$ Counselling Psychology Program, Centre for Research in Psychology and Human Well-being, Faculty of Social Sciences and Humanities, Universiti Kebangsaan Malaysia, 43600 Bangi, Selangor, Malaysia, ${ }^{2}$ Counselling Unit, Wesley Methodist School Kuala Lumpur (international), 185, jalan Lima, Sentul Selatan, 51000 kuala Lumpur, Wilayah Persekutuan Kuala Lumpur

${ }^{3}$ Centre of Community Education and Well-being, Faculty of Education, Universiti Kebangsaan

Malaysia, 43600 Bangi, Selangor, Malaysia, ${ }^{4}$ Faculty of Social Sciences and Humanities, Universiti Teknologi Malaysia, 81310 Skudai, Johor, Malaysia, ${ }^{5}$ International Medical University, 57000 Kuala Lumpur, ${ }^{6}$ Shin Pui San Illustration, No 1, Laluan Sri Ampang, 4, Kampung Ampang Baru, 31350, Ipoh Perak

Email: salina.nen, stchong@ukm.edu.my

\begin{abstract}
Metaphoric cards as a tool in counselling sessions are getting more scholarly attention in the fields of career counselling and education. In general, metaphoric cards consist of visual image that depicted daily life events and human expressions which are used as an alternative form of expression other than verbal communication. This paper aims to introduce metaphorical drawing as the experiential learning method in teaching narrative career counselling course. This is a qualitative study consists of metaphorical drawing and written reflection with six participants by using thematic analysis research method. The metaphorical drawing results revealed that, two new themes had been emerged in the exploration of work value and identity status. The results showed that some but not all participants benefited from the metaphorical drawing session to fully express their identity statuses. However, the combination of written reflection and verbal explanation of the metaphorical drawing did help the participants to convey their identity concern. In conclusion, metaphorical drawing session could be adopted in counsellor education to promote more understanding of narrative counselling technique and also in teaching work value and career identity status. For future research, it is important to look into how metaphorical technique can be introduced to school students in understanding their career choices.
\end{abstract}


INTERNATIONAL JOURNAL OF ACADEMIC RESEARCH IN PROGRESSIVE EDUCATION AND

DEVELOPMENT

Vol. 10, No. 1, 2021, E-ISSN: 2226-6348 @ 2021 HRMARS

Keywords: Metaphoric Card, Narrative Career Counseling, Work Value, Identity Status, Experiential Learning

\section{Introduction}

Metaphoric Drawing Narrative Career Counselling: Teaching Work Value and Career Identity Statuses via Experiential Learning Method

Educating future counsellors often involves teaching them abstract concepts relating to counselling that requires personal experience and practice to fully understand. This necessity for personal guidance often makes it difficult for counselling students to understand when taught in a classroom environment. This study was devised from a constructivist perspective that emphasizing individuals actively constructing knowledge through engaging in experiences, reflecting upon them, and comparing their current experiences to pre-existing assumptions (Andresen, Boud, \& Cohen, 2000). This is in contrast to traditional teaching practices of transmitting knowledge where constructivism holds that individuals are always more or less instrumental in their own learning. It was hypothesized that said individuals learn best through thinking about and subsequently integrating the learnt knowledge with their own diverse experiences (Hayes \& Oppenheim, 1997; Kolb, 1984).

Counseling concepts of the narrative career counselling process like the work adjustment theory and career identity statuses theory are particularly difficult concepts for up and coming counselors to properly understand. The reasoning behind its difficulty is due to its subjective manner of conduct and interpretation which may differ from one counsellor to another thus making it a difficult subject for educators to properly teach through traditional teaching practices. On the other hand, using experiential learning methods could be a better alternative for educating counselling students on the more abstract and/or subjective concepts of the counselling field.Taking this into account, this current study intends to study whether the use of metaphoric drawings will make it easier for counselling students to better understand the concepts and application of the narrative career counselling process in a real-life setting. With that said, the three variables that will be focused upon; the narrative career counselling process, work adjustment and career identity statuses and the use of metaphoric drawing as an experiential learning method.

\section{Narrative Career Counselling}

Proper career planning is important if one desires to establish a fulfilling life for themselves. A study by Quan-Baffour and Arko-Achemfuor (2014) affirms this statement with its findings whereby individuals who were more influenced by outside variables had lower job satisfaction in their future careers compared to individuals who were personally motivated by self-interest and took initiative in deciding their career paths. These results are exactly why the presence of counsellors and career counselling practices are so important for individuals who still unclear on what they would like to accomplish as a career in the future. One such method that counsellors can employ during a career counselling session is the Narrative Career Counselling style. Narrative Career Counselling is a qualitative assessment that's pre-dominantly based upon constructivism (McMahon \& Patton, 2002; McMahon, Patton, \& Watson, 2003; Whiston \& Rahardja, 2005). It adapts concepts from both the Systems Theory Framework (STF)(Patton \& 
McMahon, 2006) and Theory of Career Construction (Savickas, 2005). According to Mcilveen and Patton (2007), STF emphasizes an individual's perception of the influences in his/her life, includes interpersonal, social and environmental influences. It helps to provide a broad heuristic view through the construction of a person's story allowing said individual to make sense of the multiple influences upon their career choices.

On the other hand, career construction theory (Savickas, 2005) explained that the interpretative and interpersonal processes through which individuals are exposed to impose meaning and direction on their vocational behaviors/choice. The theory emphasizes the subjective experiences that each individual experience through their career journey as well as how said individuals create thematic stories that match with their life and career story. Basically, narrative career counselling employs both concepts in their practices. By doing so, counsellors are able obtain a better understanding of not only a client's past and present career choices but also their primary internal and external influences that have heavily influenced their career choices up to that point. By doing so, counsellors are able to determine and guide clients towards making the most appropriate career choices for themselves. A key feature of Narrative Career Counselling is its usage of story or personal narrative. According to Baumeister and Newman (1994), a personal narrative describes a story that represents a person's life and how they have made sense of their own personal experiences. McAdams and McLean (2013) described individuals as 'Natural Storytellers' creating narrative descriptions not only for their own experiences but also for others based on their past part actions and stories that makes sense of actions taken by said individuals (Polkinghorne, 1988).

Narratives or stories help people to find meaning in what they are doing or striving to do (Gibson, 2004). Through said stories, people are not only portraying their identities but also concurrently constructing their identities (Botella, Herrero, Pacheco, \& Corbella, 2004; Gibson, 2004). The main practice of narrative career counselling has been summed up by McAdams and McLean (2013) as "the practice of telling, retelling, reinterpretation, and editing of stories about their experiences with individuals eventually developing an integrated narrative identity". McAdams and McLean (2013) further elaborates that a person's narrative identity is their internalized and evolving life story that integrates the reconstructed past and imagined future to ensure a life with some degree of unity and purpose. This definition is supported by Habermas and Bluck (2000) who states that people come to understand themselves by telling stories about themselves, relating past stories to present circumstances in a causal and thematic way to establish a sense of self-continuity and self-understanding.

In practice, the counsellor and client cooperate to relive and reconstruct a client's past history (Brott, 2001; Savickas et al., 2009). While the meaning-making process is done cooperatively between client and counsellor, the process still places an emphasis on the client over the counsellor. The counsellor's role in this process is to help facilitate the client's personal development and redevelopment of their personal career narrative (Chen, 2002; McMahon, 2006). It is through this process that the client is able to confidently make career based decisions by seeing who they are in terms of personal meaning rather than in the objective terms of a test score, an occupation, or a career category (Gibson, 2004) However, one thing that counselors 
need to be aware of is how their own influence may affect how the client depicts their personal story and take steps to mitigate any effect it may have on the client. Clients who are more emotionally vulnerable have tendencies towards appeasing their designated counselors during sessions, telling them what they think the counselor would like to hear. This is often to avoid potential emotional distress originating from the counselor. Such actions would inadvertently affect the story telling process and ultimately the results of the counseling sessions. Counselors will need to be aware of this possibility and ensure the client that it's not their fault if mistakes are made or the results of the sessions are not to the expectation of the counselor.

\section{Work Adjustment Theory/Career Identity Statuses}

In conjunction with narrative career counselling, the present study will also be placing an emphasis on both work adjustment theory and a person's career identity statuses.

Work adjustment theory was developed by Dawis \& Lofquist (1984), a comprehensive personenvironment correspondence theory that predicts worker adjustment from the interaction between workers' personalities and their work environment. Following this theory, an individual's work adjustment is measured by both their work satisfaction and work satisfactoriness. Satisfaction within this context refers to the extent in which a worker's needs are being met by available reinforcers in the work environment whereas Satisfactoriness refers to their ability to adapt and fulfil the requirements of their current occupation. According to Lofquist and Dawis (1978), using a six-factor structure provides the most accurate representation of an individual's adjustment. These six factors or "values" are achievement, altruism, autonomy, comfort, safety, and status. In relation to these 6 factors, Lofquist and Dawis (1978) also conceptualized three bipolar dimensions; achievement versus comfort, altruism versus state and safety versus autonomy. These 3 dimensions represent what an individual might be looking for within a specific career choice and is split between concepts of self (achievement, autonomy), social (altruism, status) and environment (comfort, safety). By referring to this concept, we can see that each individual places different emphasis on different variables when considering their current station in life and the fulfilment or lack of said variables will undoubtedly affect both their work satisfaction and satisfactoriness.

On the other hand, career identity, also referred to in literature as occupational identity and vocational identity, is used here to refer to a core structure within one's sense of self "characterized by clarity, coherence, and stability of perceived occupational motivation and abilities" (Skorikov \& Vondracek, p. 143). Marcia et al. (1993) believed that for an individual's identity status to be formed it first requires the presence of a 'crisis' and a 'commitment'. Following this, Marcia et al (1993) theorized that depending on the result of said crisis, the individual will fall into one of four groups; Identity Diffusion, Identity Foreclosure, Identity Moratorium and Identity Achievement. The moratorium status describes an individual who is currently exploring but have not yet committed themselves to the various dimensions of identity. The Identity achievement status refers to persons who have gone through a period of exploration and have emerged with a clear commitment to their identity status. The foreclosure status refers to persons who have attained a firm level of commitment by adoption the attitudes of their peers 
and role models without deliberation or exploration. The diffusion status is characterized by an absence of both exploration and commitment.

\section{Metaphoric Drawing as an Experiential Learning Method}

Educating future counsellors and therapists can often times be a challenging task. This is often due to the ambiguity and lack of objective guidelines for teachers and educators to pass on to their students. This is especially true for counselling subjects that work with concepts that are often subjective, requiring the counsellor's personal interpretations. Narrative career counselling is considered one such topic in which counsellors need to cooperate with each individual client's subjective experiences and help guide them towards making the right career choice. With that said, it is believed that through the usage of creative activities, lessons and concepts would be conveyed in a smoother and easier manner. A study conducted by Deaver and McAuliffe (2009) sought to prove this theory through their qualitative study. Their study involved the use of reflective visual journaling to educate counselling students and art therapy students during their internships. The results of the 15 -week study found that participants obtained greater insights into aspects of their experience when their reflections were combined written texts. All participants of the study considered the combination of art making and responsive writing to be particularly effectively aspect of their experience. Similarly, visual journaling is perceived by counselling and art therapy interns to be effective in facilitate the process of reflection (Deaver \& McAuliffe, 2009). In another study, Ingebrethsen (2013) highlighted the used of metaphors to communicate abstract ideas through visual expression in drawings. Together, these studies indicate that metaphoric drawing can be used as a creative means to facilitate experiential learning process.

\section{Method}

\section{Research Design}

This research aims to explore the use of metaphoric drawings in a narrative career counselling group on identifying participants' work value and career identity statuses. Hence, the focus of this study was on identifying the metaphor, meaning and participants' interpretation of their drawings in representing their work values and career identity statuses. This narrative career counseling session was led by a lecturer and assisted by a research assistant for 3 hours. A total of six postgraduate students counselling psychology students was recruited based on the specific inclusion criteria. Participants were briefed about the research procedure, handling of the data as well as the adherence to ethical standard with regard to anonymity and confidentiality. At the end of session, participants were invited to share their perceptions and experience of using metaphoric drawing in identifying their work values and career identity statuses. A video-camera recorded the whole session as well as post session discussion. Below is a diagram which shows the overview of the research process. 
Vol. 10, No. 1, 2021, E-ISSN: 2226-6348 @ 2021 HRMARS

\section{Figure 1}

An overview of the Research Process

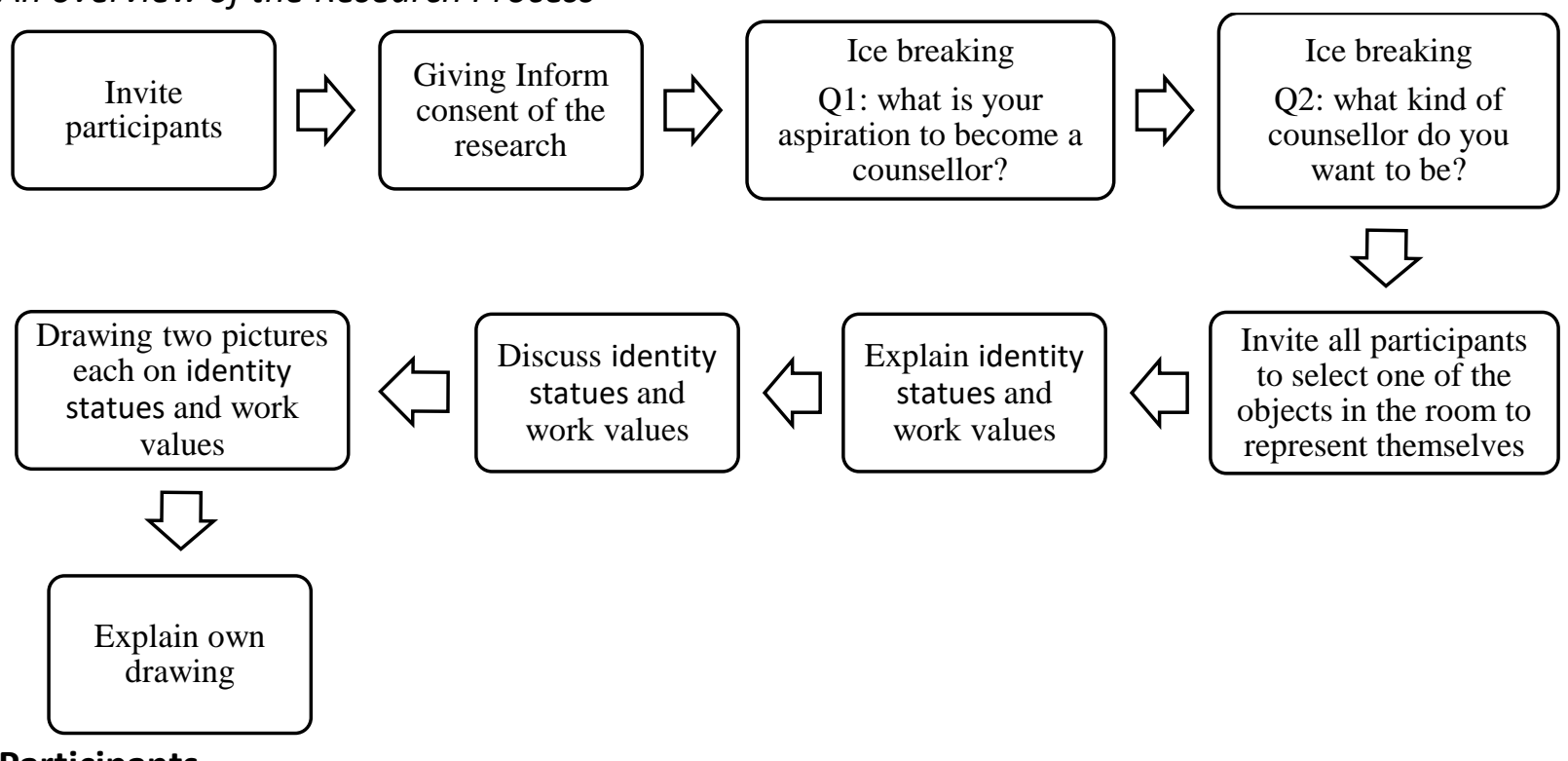

\section{Participants}

Convenient sampling was selected in this study. According to Howitt \& Cramer (2014), convenient sampling is not random samples of anything, but groups of people that are relatively easy for the researcher to get to take part in their study. The participants in the study consisted of 5 graduate students and a doctoral student ( 2 males and 4 females) from the Faculty of Social Sciences and Humanities, the National University of Malaysia. The age range of the respondents was from 24 to 34 years (average of 28.3 years).

Table 1

Participants' background

\begin{tabular}{lllllll}
\hline & P1 & P2 & P3 & P4 & P5 & P6 \\
\hline Age & 26 & 27 & 32 & 26 & 25 & 34 \\
Gender & Male & Female & Female & Female & Male & Female \\
Higher & Degree in & Degree in & Degree in & Degree in & Degree in & Master in \\
Educatio & Psychology & Psycholog & Psycholo & Medical & Usuluddi & Guidance \\
$\mathbf{n}$ & & y & gy & & n & Counselli \\
& & counselin & counselin & & Counseli & ng \\
& & g & g & & ng & \\
\hline
\end{tabular}

\section{Procedure}

In the beginning of the session, participants were provided with art materials like acrylic, water color, crayon, colour pencil, magic colour and two drawing blocks (A3 size). An ice-breaking was conducted where respondents were asked to name one item that was most suited to introduce themselves. Then a short discussion on their personal journey in becoming counsellors and their motivations to pursue this goal. The research facilitator further explained the identity statues and work values that might match respondents' circumstances. The researcher begins with the 
discussion of the first question: "What is your aspiration to become a counsellor?". Most participants responded to their experiences such as aspirations to learn the process of communication from family interactions, early childhood experiences, experiences during practicum at hospital, bullying experiences in elementary school, family member were rejected by the school, emotional problems, trying to learn new subjects and the opportunity to become a school counsellor. Then the researcher further the discussion with question: "What kind of counsellor do you want to be?". Some participants wanted to be community counsellor focused on children and youth; counsellor focused on community outreach programs with systematic planning; counsellor focused on minority groups such as LGBT groups and mental health; advocator on parenting or family issues in pre-marital and counsellor who wish to study analytical therapy. The researcher concludes that motivation in this career is a combination of personal values and work values and shows who you are.

After the discussion, the trainees were asked to draw anything that could represent their identity statuses and work values. About an hour was given for the respondents to finish the art piece. After that, they were asked to write a short description of their art pieces. Next, the researcher asks all participants to select one of the objects in the room to represent themselves. Participants choose different objects to representing:

1. a set of watercolours of different colours, which, although widely used, can be consumed quickly but are capable of colouring the lives of others and themselves;

2. the slogan of 'have a break have a KitKat' represented enough rest;

3. sets of crayons with different colours representing different knowledge can be used;

4. to be a door rail that represents the way out, new opportunities for others;

5. a cup that can fill any need and the cup is always there as a promise to a friend;

6. the green represents the vibrant spirit that wants to embody the life of the people around it.

The researcher further describes the 4 identity statues: achievement, moratorium, foreclosure and diffusion with factors empowerment and commitment. After explanation, the researcher asked participants to think about their identity status and share in the group. Subsequently, the researcher also explained the 6 values of work which are achievement, altruism, comfort, status, safety and autonomy by giving examples. Participants were also asked to think and share their values in the group. Lastly, participants were given one hour to draw a picture that represented the identity status and a picture representing the work value. Participants in addition to sharing the drawing were asked how they felt about the overall process and how the process differed between the two outcomes.

\section{Qualitative Measures}

This study aims to explore the use of metaphoric drawing in conducting a narrative career counselling in a group setting. A qualitative metaphor analysis was used to identified the similar metaphor drawn by the participants in this study. Moser (2005) and Schmitt (2005) both expressed the possibilities to work with metaphors by elicit them directly from the research participants. Qualitative measures used included the metaphoric drawings and discussion after drawing. The art pieces were not judged in terms of art value but how it could help the 
respondents to express the exploration and commitment in their career paths and the work values which were important to them. After transcript the process of data collection is the first phrase of thematic analysis which called data familiarization. Researcher begin to formulate pattern from the data collection and would enter to second phrase, initial coding generation. This study dominated by the characteristic of the data and analysis data with carefully to generate a primary coding. In third phrase, researcher search for themes based on the initial coding. Then reviewing themes after set of candidate themes. Next phrase is theme definition and labelling as will describe in result. Lastly is report writing.

\section{Results}

The following are interpretations that were derived from the data collected from the participants of this study in relation to both concepts of Identity Statues and also Work Values.

\section{Identity Statuses \\ Moratorium Stage}

Based on the interpretations presented by the participants, certain observations can be made. As expected, the concept of exploration is easily identified in the pieces of art presented by the participants $\mathrm{P} 1 \mathrm{a}, \mathrm{P} 4 \mathrm{a}$ and $\mathrm{P} 6 \mathrm{a}$. This is seen through their usage of multiple paths or the explosion of various colors. This coincides with the Moratorium stage which is associated with active exploration with an absence of commitment.

\section{Figure 2}

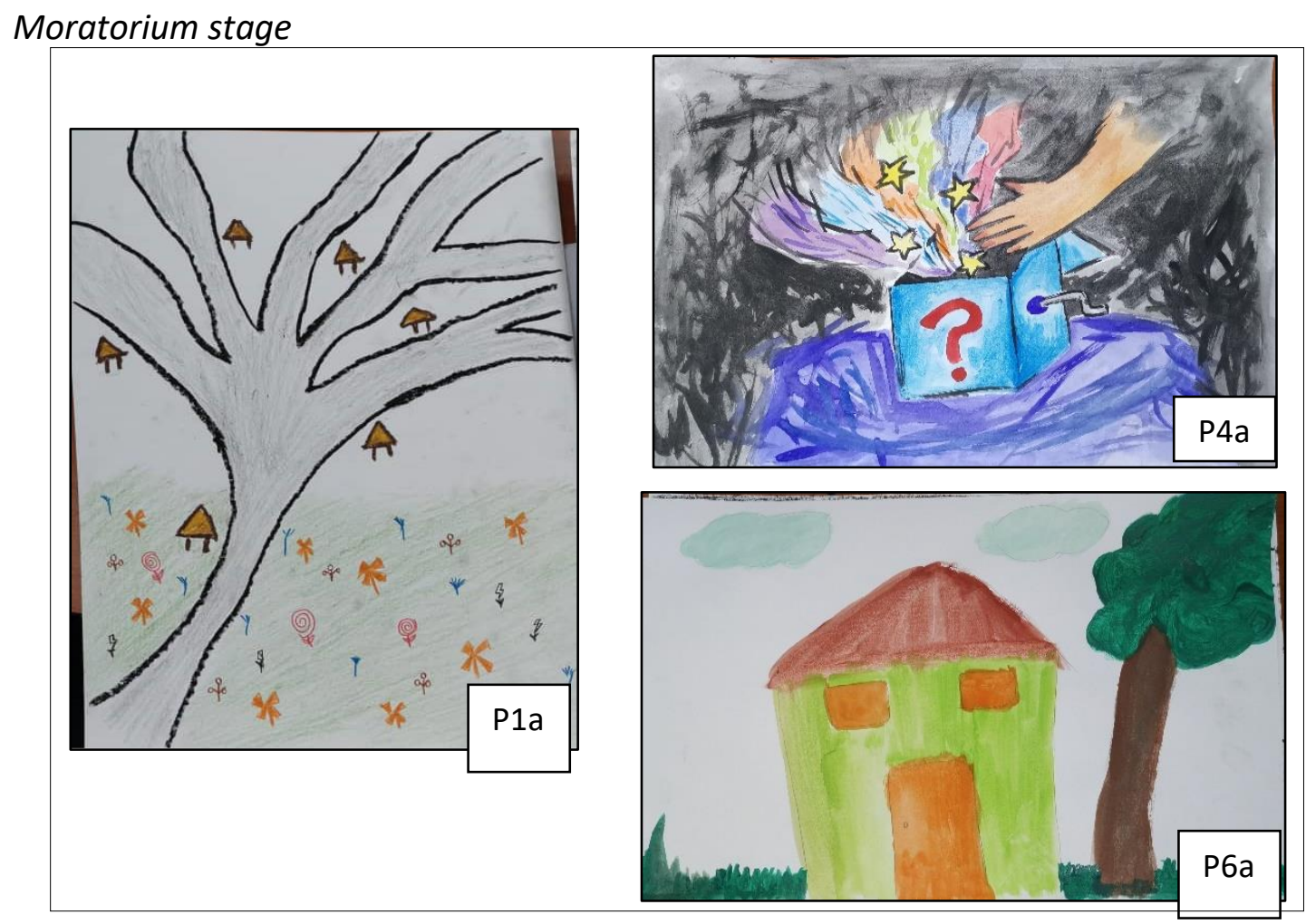

* a: drawing on identity status; $b$ : drawing on work value 
However, an individual's reasoning behind their inability to commit to a specific path can differ from person to person as seen in the images provided. P1a and P6a remarks that the reasoning behind their lack of commitment and intent on exploration without commitment is due to having too many possible options for them to choose from thus causing indecisiveness whereas in the opposing image P4a describes the search as a response to a personal dilemma of being lost without a solution (a light) in sight.

\section{Identity Achievement Stage}

Similarly, to the previously discussed Moratorium stage, certain observations can be made while interpreting the drawings provided by participants $\mathrm{P} 2 \mathrm{a}, \mathrm{P} 3 \mathrm{a}, \mathrm{P} 5 \mathrm{a}$ and $\mathrm{P} 6 \mathrm{~b}$.

\section{Figure 3}

Identity achievement stage

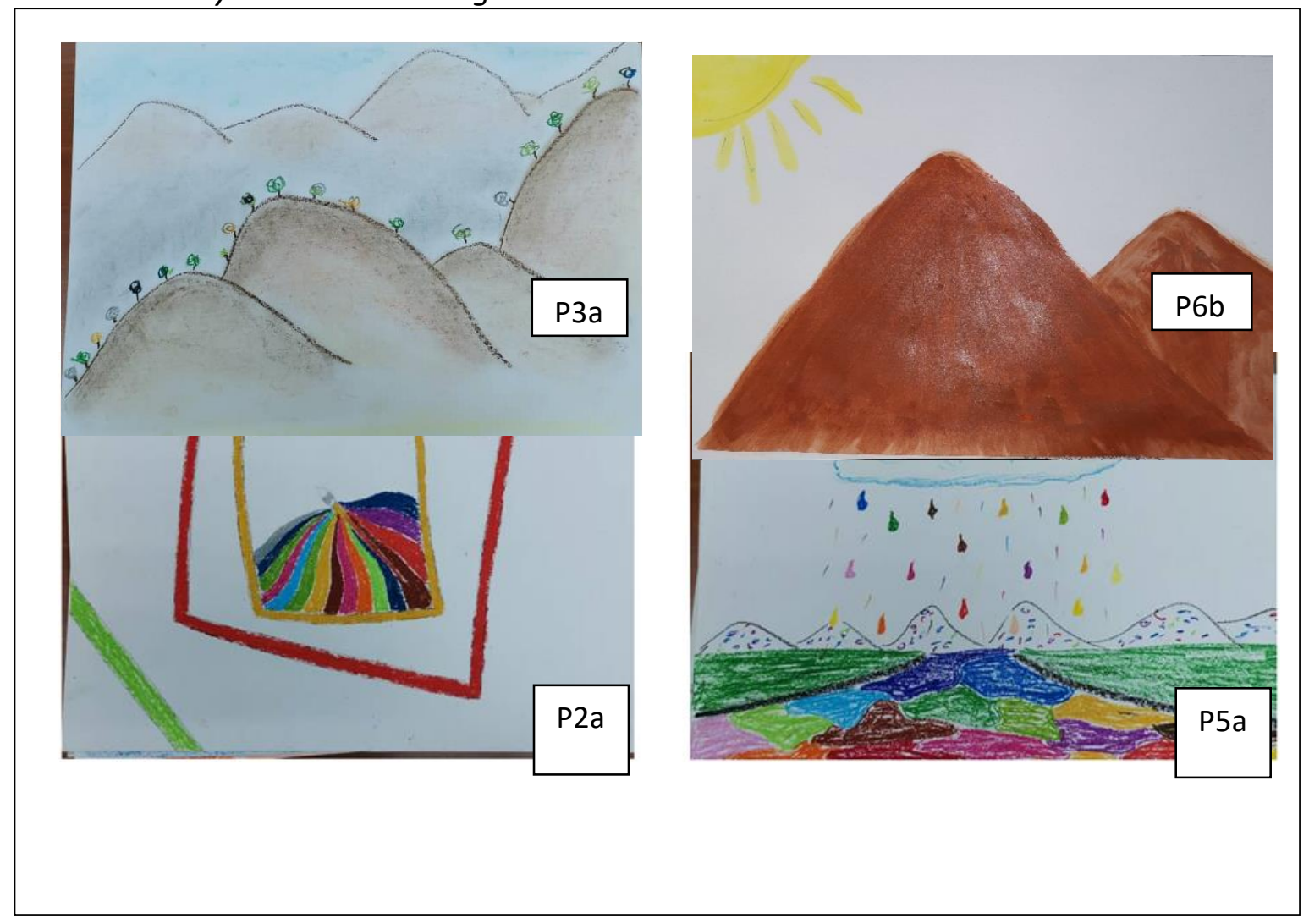

** a: drawing on identity status; $b$ : drawing on work value

A sense of completeness was reported by four participants with all four participants being fully committed to seeing their chosen path reach their eventual conclusion. Another similarity that can be derived from these images is the participants' usage of various colors that can be interpreted as a sense of fulfillment and/or satisfaction in their own vocational choice. However, there is a difference in how these participants have perceived their own state of achievement. P5a described their state as if it were a well-oiled machine where every supporting aspect of their choice is perfectly supporting each other. This is seen through their art whereby they perceive 
their work life as if it were a work of nature as seen through their usage of rivers, rain and flora. In contrast to this depiction, P2a, P3a and P6b instead chose to perceive their vocational choice as merely a single step in their vocational journey which is a new theme that the researchers found. This was interpreted from their drawings in which there is a sense of journey and progression presented as seen through their usage of hills and valleys and constantly expanding boxes.

\section{Work Values}

Safety

P3b's drawing on work value involved the usage of trees that have been planted close to one another. We can reasonably assume that this individual place great importance on having a sense of camaraderie in the workplace. The usage of trees in their art also allows us to assume that the participant prefers to be in an environment in which they are supported by co-workers who might be more experienced individuals. This was interpreted through their drawing depicting a smaller tree being surrounded by many taller and bigger trees.

\section{Altruism}

The first thing that stands out is the usage of bright lights and/or colors in an environment which is a new theme that suggested in this research. This is noticeable in the drawings, with a bright orange beam cutting through a dark bluish wall. P2b's drawing on work value considered vocational choice as a sort of guiding light, allowing to help others who require the 'light' (help). This motivation is intensified by the perception that individuals who have the necessary means to help those that are in actual need. $\mathrm{P} 2 \mathrm{~b}$ explains the vocational choice being a result of wanting to make a difference in the lives of others with the other explaining their choice being a result of wanting recognition as a result of their efforts.

\section{Autonomy}

A common theme that could be derived from the participants of this group is the concept of control. P4b and P5b both described their definition of Autonomy being a sense of total control over their own decisions and being able to take responsibility for themselves. Both participants drew a fist grasping an object which could be interpreted as them taking responsibility and action towards their future aspirations. Both P4b and P1b described their vocational choice as their way of making decisions for themselves without being influenced by outside parties. On the other hand, P1b presented a differing view on the concept of Autonomy. According to the participant, the amount of autonomy an individual is allowed is limited and is often affected by outside influences. This is explained by the participant whereby they describe life as rigid and lacking personal control. This is further emphasized through their usage of dices in their artwork which is primarily used as a symbol of chance and randomness. 
Vol. 10, No. 1, 2021, E-ISSN: 2226-6348 @ 2021 HRMARS

\section{Figure 4}

\section{Autonomy}

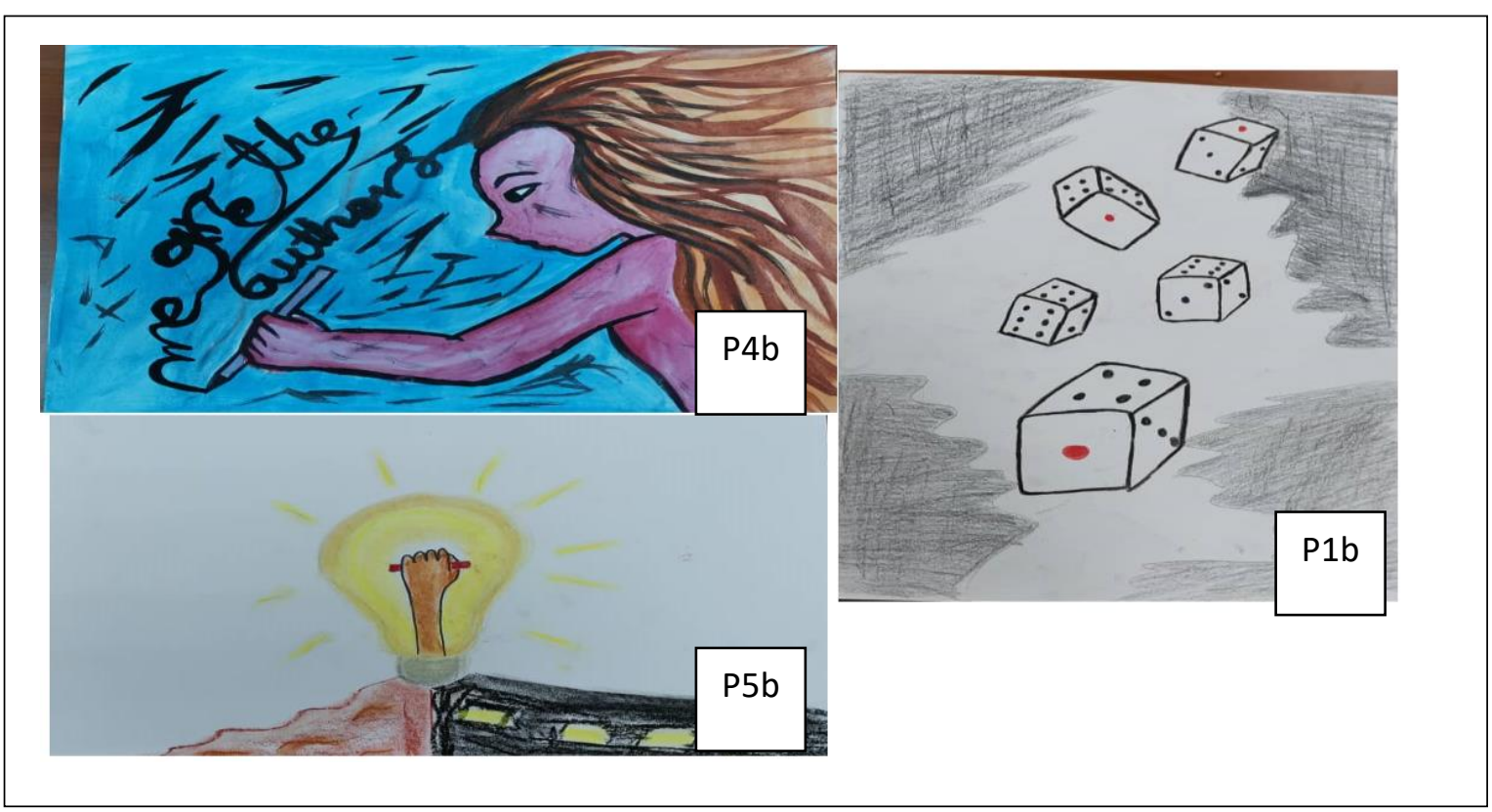

** a: drawing on identity status; $b$ : drawing on work value

\section{Conclusion}

Narrative career counseling is difficult to properly convey in a traditional classroom-based teaching setting because of its subjective nature. Hence this paper introduced an alternative method to convey its lesson using experiential learning methods. For this paper, metaphoric drawing is introduced as the alternative method. Students were required to share about their career journey through their own personal drawings with explanations. A brief discussion was held to find out participants' reflection after the drawing session. Participants revealed that the activity helped them to externalize their own motivations behind their past career decisions. Participants also commented that this non-verbal exercise made it easier to convey what they were experiencing. As such, it is believed that the use of metaphoric drawing exercises as an alternative teaching method to narrative career counselling should be recommended. With that said however, it must be stated that this research has had certain limitations. One such limitation is that due to the subjectivity of the activity, participants that are less artistically inclined will have difficulty producing their own set of artworks for the study thus making it difficult to the study to proceed further. Another limitation found is, participants who are less expressive will find it difficult to explain the meaning behind their drawings after they have completed them. This again makes it difficult to proceed with the study.

Following these limitations, it is recommended that the facilitator be someone who is capable at properly guiding the participants as to avoid the participants from getting confused. Other than that, it is recommended that participants who choose to participate in the study are made aware of the need to create illustrations and also the need to later explain the meaning behind them. This is to ensure that participants who consider themselves, non-artistically inclined, will choose 
to not participate in this study. Finally, the research has revealed several implications. The first is that the use of metaphoric drawings as a tool in a narrative career counseling context would make it easier for clients to express themselves if they find it difficult to do so verbally. In addition, it's also been shown to successfully reveal certain motivations and reasons for client career choices that even the clients themselves may not have been initially aware of before. Another implication that we can surmise from the study is that the use of metaphoric drawings as an experiential learning method has shown merit but it will require further research to properly explore how extensive its applicability actually is.

\section{Acknowledgement}

This research was supported by Geran Galakan Penyelidikan, Universiti Kebangsaan Malaysia (GGP 2019-018).

\section{References}

Andresen, L., Boud, D., \& Cohen, R. (2000). Experienced-based learning. In G. Foley (Ed.), Understanding adult education and training (2nd ed.) (pp. 225-239). Allen \& Unwin.

Balistreri, E., Busch-Rossnagel, N. A., \& Geisinger, K. F. (1995). Development and preliminary validation of The Ego Identity Process Questionnaire. Journal of Adolescence, 18(2), 179192.

Baumeister, R. F., \& Newman, L. S. (1994). How stories make sense of personal experiences: Motives that shape autobiographical narratives. Personality and Social Psychology Bulletin, 20, $676-690$.

Braun, V., \& Clarke, V. (2006). Using thematic analysis in psychology. Qualitative Research in Psychology, 2(2), 77-101. http://dx.doi.org/10.1191/1478088706qp063oa

Brott, P. E. (2001). The storied approach: A postmodern approach to career counseling. The Career Development Quarterly, 54, 13-149. https://doi:org/10.1002/j.21610045.2001.tb00958.x

Botella, L., Herrero, O., Pacheco, M., \& Corbella, S. (2004). Working with narrative in psychotherapy. In L. E.Angus \& J. McLeod (Eds.), The handbook of narrative 62 Australian Journal of Career Development 27(2) and psychotherapy: Practice, theory and research (pp.119-136). Sage Publications Inc.

Chen, C. P. (2002). Enhancing vocational psychology practice through narrative enquiry. Australian Journal of Career Development, 11, 14- 21.

Creswell, J. W., \& Clark, V. L. P. (2018). Designing and Conducting Mixed Methods Research. $3^{\text {rd }}$ Ed. Sage Publications Inc.

Deaver, S., \& McAuliffe, G. (2009). Reflective visual journaling during art therapy and counselling internships: a qualitative study. Reflective Practice, 10(5), 615-632. https://doi.org/10.1080/14623940903290687

Dawis, R. V., \& Lofquist, L. H. (1984). A psychological theory of work adjustment: An individual differences model and its applications. University of Minnesota Press.

Dawis, R. V., \& Lofquist, L. H. (1978). A note on the dynamics of work adjustment. Journal of Vocational Behavior, 12, 76-79. 
INTERNATIONAL JOURNAL OF ACADEMIC RESEARCH IN PROGRESSIVE EDUCATION AND

DEVELOPMENT

Vol. 10, No. 1, 2021, E-ISSN: 2226-6348 @ 2021 HRMARS

Gibson, P. (2004). Where to from here? A narrative approach to career counseling. Career Development International, 9, 176-189. https://doi10.1108/13620430410526201

Hayes, R., \& Oppenheim, R. (1997). Constructivism: Reality is what you make it. In T. Sexton \& B. Griffin (Eds.), Constructivist thinking in counseling practice, research, and training (pp. 1940). Teachers College Press.

Habermas, T., \& Bluck, S. (2000). Getting a life: The emergence of life story in adolescence. Psychological Bulletin, 126, 748-769. https://doi10.10370T033-2909.126.5.748

Howitt, D. (2016). Introduction to Qualitative Methods in Psychology ( $3^{\text {rd }}$ ed.). Pearson Education Limited.

Howitt, D., \& Cramer, D. (2014). Introduction to Research Methods in Psychology (4 ${ }^{\text {th }}$ Ed). Pearson Education Limited.

Hughes, A., Gibbons, M., \& Mynatt, B. (2013). Using Narrative Career Counseling with the Underprepared College Student. The Career Development Quarterly, 61(1), 40-49. https://doi.org/10.1002/j.2161-0045.2013.00034.x

Ingebrethsen, B. (2013). Drawing with Metaphors. Mediating ideational content in drawing through metaphors. FormAkademisk - Research Journal of Design and Design Education, 6(3). https://doi.org/10.7577/formakademisk.744

Leong, F. T. L. (editor). (2008). Encyclopedia of Counselling. Sage Publications Inc.

Marcia, J., Waterman, A., Matteson, D., Archer, S., \& Orlofsky, J. (1993). Ego Identity. Springer New York.

McAdams, D. P., \& McLean, K. C. (2013). Narrative identity. Current Directions in Psychological Science, 22, 233-238. https://doi10.1177/0963721413475622

Mcilveen, P., \& Patton, W. (2007). Narrative career counselling: Theory and exemplars of practice. Australian Psychologist, 42(3), 226-235. https://doi.org/10.1080/00050060701405592

McMahon, M., \& Patton, W. (2002). Using qualitative assessment in career counselling. International Journal for Educational and Vocational Guidance, 2, 51 - 66.

McMahon, M., Patton, W., \& Watson, M. (2003). Developing qualitative career assessment processes. Career Development Quarterly, 51, 194 - 201.

Mertens, D. M. (2015). Research and Evaluation in Education and Psychology: Integrating Diversity with Quantitative, Qualitative, and Mixed Methods. $4^{\text {th }}$ Ed. Sage Publications Inc.

Moser, K. S. (2000). Metaphor Analysis in Psychology-Method, Theory, and Fields of Application. Forum: Qualitative Social Research, 1(2), Art. 21

Patton, W., \& McMahon, M. (2006a). Career development and systems theory: Connecting theory and practice. Sense Publishers.

Polkinghorne, D. E. (1988). Narrative knowing and the human sciences. State University of New York Press.

Quan-Baffour, K., \& Arko-Achemfuor, A. (2014). The Effects of a Lack of Career Pathing on Job Satisfaction Among South African Teachers. Africa Education Review, 11(1), 1-16. https://doi.org/10.1080/18146627.2013.853564 
Savickas, M. (2005). The theory and practice of career construction. In S. D. Brown, \& R. W. Lent (Eds.), Career development and counseling: Putting theory and research to work (pp. $42-$ 70). John Wiley \& Sons.

Schmitt, R. (2005). Systematic Metaphor Analysis as a Method of Qualitative Research.The Qualitative Report, 10(2), 358-394.

Schwartz, S. J., Mullis, R. L., Waterman, A. L., \& Dunham, R. M. (2000). Ego Identity Status, Identity Style, and Personal Expressiveness. Journal of Adolescence Research,15,504-521.

Skorikov, V. B., \& Vondracek, F. W. (2007). Vocational identity. In V. Skorikov \& W. Patton (Eds.), Career development in childhood and adolescence (pp. 143-168). Rotterdam, The Netherlands: Sense.

Whiston, S. C., \& Rahardja, D. (2005). Qualitative career assessment: An overview and analysis. Journal of Career Assessment, 13, 371 - 380. 